\title{
Politics of Cultural Tourism in the North Sumatera Samosir Island
}

\author{
Mangihut Siregar ${ }^{1}$ \\ ${ }^{1}$ Political Science Magister, FISIP, Wijaya Kusuma Surabaya University, Indonesia \\ Correspondence: Mangihut Siregar, Political Science Magister, Wijaya Kusuma Surabaya University, \\ Surabaya, Indonesia. E-mail: msiregar22@yahoo.com
}

Received: March 5, 2020; Accepted: March 25, 2020; Published: March 31, 2020

\begin{abstract}
Tourism has become a very promising industry in increasing economic development. Each region is competing to market their area as a tourist destination in order to get foreign exchange. All resources, such as natural resources, human resources, special interest resources, especially cultural resources, are all maximized for the advancement of tourism.

In an effort to increase regional income, the Samosir Regency Government of North Sumatra Province took a breakthrough to attract tourists to visit Samosir Island. One of the efforts made is by demonstrating cultural tourism, which is the ritual performance of mangalahat horbo bius ritual. This show is held every year in the Horas Samosir Fiesta event. The mangalahat horbo bius ritual performance began in 2008 at Batu Hobon, Limbong Sagala Village, Sianjur Mulamula Samosir Sub District. Since it was made a ritual, the mangalahat horbo bius became a show on Samosir Island, there were pros and cons in the community where the Catholic Church supported the show as the way to spread religion. Meanwhile the Samosir Regency government as the initiator of the show, has the aim to attract the interest of the visit. The party who openly rejected the show was the Batak Christian Protestant Church (HKBP).

Since the beginning, the mangalahat horbo bius ritual performance has experienced controversy in the community. The aim is to attract visits to the Samosir Island area to be counter productive. Therefore, at every mangalahat horbo bius ritual performance, the number of tourist visits to Samosir Island always decreases. In this case the local community is less supportive of the show while tourists visiting Samosir Island avoid the mangalahat horbo bius ritual show for reasons of showing sadism.
\end{abstract}

Keywords: politics of cultural tourism, power, ideology, controversy

\section{Introduction}

Tourism today has become one of the largest industries in the world so it has become the mainstay for generating foreign exchange. Some countries that depend heavily on foreign exchange through tourists visiting their regions are Thailand, Singapore, the Philippines, Fiji, Maldives, Hawaii, Tonga, Galapagos, Barbados, the Caribbean Islands, and several other countries. The large number of visits is usually directly proportional to the amount of foreign exchange that enters the destination.

Seeing the success of several regions through tourism foreign exchange, the Samosir Regency Government adopted a new policy by conducting a politics of cultural tourism. The decision of the Samosir Regency Government's to appoint the mangalahat horbo bius ritual to be a show with the aim of attracting visitors to Samosir Island. To succeed in their desire, the Samosir Regency Government worked with several traditional leaders and Catholic religious leaders. Traditional leaders strongly support the performance of this ritual because their existence as the king of bius (raja bius) come back. The Catholic religious leaders agree to the mangalahat horbo bius as a means to broadcast religion.

Although the Samosir Regency Government has collaborated with several traditional leaders and Catholic religious leaders in North Sumatra, the mangalahat horbo bius ritual performance did not go smoothly. A group that strongly rejects this show, the Batak Christian Protestant Church (HKBP), arguing that it is contrary to God's word and displays sadism. Rejection from some people resulted in this ritual performance always controversial and counterproductive to attract interest in a visit to Samosir Island. Every mangalahat horbo bius ritual performed on Samosir Island, the number of visits is always reduced. However, through the power held by the Samosir Regency Government, the ritual performance was still performed. The Samosir Regency Government made this performance a project so that it had to continue. 


\section{Method}

In this study it was used qualitative methods. Qualitative research is research that seeks to analyze social life by describing the social world from the view of informants with a natural setting. Thus, qualitative research explains how everyone sees, illustrates and understands his social world (Martono, 2015: 211). The subject's experience can be known through behavior, perception, motivation, action, etc. holistically. The whole is described through words holistically using natural methods (Moleong, 2014: 6).

Research on the politics of cultural tourism on Samosir Island was carried out through in-depth interviews with community leaders, Catholic religious leaders, Christian religious leaders, and also the Government of Samosir Regency. Informants were determined using a purposive technique and continued with the snowball technique. This study used two data sources, namely primary data and secondary data sources. Primary data were obtained through in-depth interviews guided by interview guidelines and then developed during the interview. Secondary data is data obtained not from the first person, but can strengthen primary data. Data analysis was carried out since the research began and ended until the research report in descriptive inductive analytic.

\section{Results}

\subsection{The Mangalahat Horbo Bius Ritual Practice in the Life of the Bataks}

Literally the term mangalahat means dressing, decorating, and returning the cosmos to God. In a religious symbolic meaning, mangalahat means returning the universe of creation to the originator, the creator God (Mulajadi na Bolon) and sacrificing the earth's symbol ie buffalo sacrifice to the Creator so that it can be renewed and re-created. Horbo bius literally means buffaloes from the local population.

From the above understanding it can be concluded that the Mangalahat horbo bius ritual is a ritual of cutting a sacrificial buffalo offered to the Batak God called Mulajadi na Bolon. They do this ritual when they start working again in the fields, breeding livestock, human welfare and prosperity, ending the long year to enter the new year (mangase taon), facing prolonged drought, disease season occurring in the community, etc. In short, the purpose of this ritual is to purify oneself or atonemen in the hope of prosperity in daily life.In its development, the mangalahat horbo bius ritual was not only purification but also as a thanksgiving to their god, Mulajadi na Bolon. Their gratitude for the birth of a child, long life, last respect for parents when they die before they are buried with the criteria of saua matua (long life, having a lot of wealth, and their children succeed). Thus the ritual, mangalahat horbo bius is done not only routinely or annually, but also carried out according to the needs of the local community.

\subsection{Ritual of Mangalahat Horbo Bius Becomes a Forbidden Tradition}

The entry of the Dutch colonial into the Tapanuli region which at the same time brought missions and zending resulted in the mangalahat horbo bius tradition becoming a forbidden tradition for the Batak tribe. This ritual became a forbidden tradition due to two factors, the first of which was against the religion of the invaders. The ritual is the horbo bius, the purpose of worship is Mulajadi na Bolon, the god of the Batak tribe when embracing the Parmalim faith. The Dutch colonial goal of worship was Jesus Christ because they embraced Christianity and Catholicism.

Batak tribal beliefs are animistic because they are different from the beliefs of the (Western) invaders. It is as said by Said (2016: 59) that Westerners always control Easterners. East is positioned as a lower, mystical, backward, irrational, and traditional place. Such a view results in Batak ethnic beliefs that must be destroyed and replaced with Western religion. This change may occur as mentioned by Schreiner (2002: 11), because the Batak people open themselves to missions and zending and allow themselves to be colonized. Colonialism influenced all aspects of Batak life, such as economic, social, political, religious, cultural, and others.

The second factor causing the prohibition of the mangalahat horbo bius ritual was to disrupt the power of the invaders. In one bius (region), the population will be politically organized, either through genealogy or geography. If the bius activity continues, the community will remain united and difficult to conquer the invaders (Vergouwen, 1986: 88). Bius organizations have a profound influence on the lives of Bataks because they form a unity and regulate the structure of a functional society (Sidjabat, 1982: 73). Because the bius function disrupts the invaders, so that all traditions related to the bius including the mangalahat horbo bius ritual become a forbidden tradition.

\subsection{Mangalahat Horbo as Traditional Ceremony}

The ban on the mangalahat horbo bius ritual carried out by the Dutch in Tapanuli does not mean that mangalahat horbo does not exist at all. The people of Samosir Island often do mangalahat horbo, but not as a religious ritual but as a complement to traditional ceremonies. Mangalahat horbo procession is usually done at the time: the 
monument party, the burial of a very old person (saor matua), the celebration of one clan, the celebration of parents' birthdays, and others. Usually they do horboat to win honor (hasangapon). The mangalahat horbo they did were not bius (one area) but only close relatives.

Honor is the highest ideals for the Batak people while the other ideals are wealth and have many children (Siregar, 2019). To gain honor, the Bataks exchange other capital, namely wealth. Those who are already really rich do a traditional party with the mangalahat horbo. Poor people cannot afford it because it costs a lot. For rich people, mangalahat horbo is not a burden, but rather an opportunity to accumulate capital. Traditional ceremonies in which there are mangalahat horbo become a game arena. This is as Bourdieu meant that rich people try to keep their distance from poor people by observing mangalahat horbo in traditional ceremonies. It is true that Bourdieu said that capital can be exchanged between one capital with another capital and also capital can be accumulated between one another (Harker, 2009: 16).

The practice of mangalahat horbo carried out during traditional ceremonies is different from the ritual procession of mangalahat horbo bius. At the time of its implementation as a ritual, the participants were very many because it involved one bius (region) while when it was carried out as a traditional ceremony the perpetrators were only one close family. Another difference is the procession of implementation. When the mangalahat horbo is performed as a religious ritual, the procession must follow the standard stages and require a long time where at the top of the procession a buffalo reconnaissance is carried out. Meanwhile, the procession in the practice of mangalahat horbo in traditional ceremonies is not so necessary and the reshuffle of buffalo is not carried out, but the priority is the image. The image as expressed by Piliang (2012:329) becomes social communication in the consumer society. Through images, it creates social differences in people's lives. Image becomes a way to achieve honor (hasangapon).

\section{Discussion}

\subsection{Politic of Cultural Tourism}

Politics is competition that occurs between people, usually in one group to make policies according to their wishes (Roskin, 2016: 3). Cultural tourism is a cultural element that is shown to tourists with the aim of earning money and being enjoyed aesthetically (Picard 2006: 252). The politics of cultural tourism is a policy taken by the Samosir District Government to attract tourists to visit Samosir Island.

Samosir Island, which is surrounded by Lake Toba, is included in Indonesia's ten national flagship destinations. As a national destination, the Lake Toba area is addressed. All resources such as natural resources, human resources, cultural resources are maximized for the advancement of tourism. However, in its journey there was a raised cultural resource that was counter productive to its purpose, namely the ritual performance of the mangalahat horbo bius.

The practice of the mangalahat horbo bius ritual which was banned by the Dutch colonials resulted in this tradition being long lost from the lives of the Bataks. In the 90s, the Batak tribe performed the mangalahat horbo in the procession of traditional ceremonies. Mangalahat horbo in traditional ceremonies is less attractive and less authentic because only images are preferred. Buffaloes used in traditional ceremonies are not speared but only cut as is usual. For an attractive and authentic show, the Samosir District Government demonstrates the mangalahat horbo bius as it is done as a ritual. The ritual og mangalahat horbo bius is used as a commodity, so commodities are not only tangible goods as Fairclough (2003:39) stated. However the ritual itself becomes a selling item that brings economic benefits.

The Mangalahat horbo bius ritual performance as the first visitation attraction was held in 2008 in Batu Hobon, Limbong Village, Sianjur Mulamula Sub District, Samosir Regency. The next performance was held in 2009 in Palipi, Palipi village, Sub Palipi District; in 2013 at the Tuktuk Siadong Open Stage, Simanindo Sub District; in 2016 in the Tomok Parsaoran Tourism Village, Simanindo Sub District; in 2017 in the Tomok Parsaoran Tourism Village, Simanindo Sub District; in 2018 in the Tomok Parsaoran Tourism Village, Simanindo Sub District; and in 2019 in Tomok Parsaoran Tourism Village, Simanindo Sub District.

From the above data there are several times (in 2010, in 2011, in 2012, and in 2014) where the mangalahat horbo bius ritual performance was not held. This was not carried out because of the pros and cons related to the performance of the mangalahat horbo bius ritual. The noble aim of the Samosir Regency Government is to increase the number of visits by performing the mangalahat horbo bius ritual, which is opposed by most people on Samosir Island.

Facing opposition from the community to the mangalahat horbo ritual performance, the Samosir regency government collaborated with Catholicism. The Catholic religious leaders (Archbishop of Medan Ofm.Cam AB. 
Sinaga) acted as the ritual leader (malim parmangmang) and Father Herman Nainggolan as commentator (malim parhata). Ideally, this ritual leader is a parbaringin sect not a Catholic religious figure. This is a new thing because the role of parbaringin and traditional leaders is replaced by Catholic religious leaders.

Although the Samosir Regency government cooperated with Catholics in the mangalahat horbo bius ritual performance, the process of commodification did not go smoothly. Christians, in this case the Batak Christian Protestant Church (HKBP) who has the most followers in Samosir District and also have the largest followers in Southeast Asia (Schreiner, 2002: 9), strongly reject the ritual performances. This decisive attitude can be seen from the results of the Seminar and Workshop (Semiloka) conducted by HKBP on Tuesday, August 4, 2015 at the Guest House Nomensen HKBP District VII Samosir, Pangururan Sub District, Samosir Regency.

The Mangalahat horbo bius ritual performance that aims to attract the interest of a visit to Samosir Island is very counterproductive. From the data collected shows that at each of these ritual performances, the number of visitors is always reduced. The visitors did not like the show, but instead avoided it because in the ritual mangalahat horbo bius there was an element of violence in it. The violence that is seen is during the buffalo bombing process several times until it runs out of blood. The decreasing number of visitors at each mangalahat horbo bius ritual performance can be seen below:

Table 1. Number of Foreign and Domestic Tourits Visit to Samosir Regency by Month (time), $2012-2018$

\begin{tabular}{|c|c|c|c|c|c|c|c|}
\hline \multirow[t]{2}{*}{ Month } & \multicolumn{7}{|c|}{ Year } \\
\hline & 2012 & 2013 & 2014 & 2015 & 2016 & 2017 & 2018 \\
\hline January & 16.245 & 14.536 & 19.664 & 13.086 & 12.095 & 38.321 & 46.734 \\
\hline February & 6.966 & 8.386 & 5.504 & 7.320 & 7.642 & 10.936 & 24.969 \\
\hline March & 7.690 & 8.467 & 8.877 & 8.742 & 7.147 & 13.362 & 30.717 \\
\hline April & 9.524 & 9.255 & 9.702 & 10.589 & 6.941 & 26.621 & 36.414 \\
\hline May & 12.895 & 11.067 & 13.065 & 15.904 & 9.494 & 16.230 & 27.716 \\
\hline June & 12.722 & 13.353 & 9.823 & 12.765 & 10.030 & 51.964 & 73.986 \\
\hline July & 9.160 & 14.572 & 17.488 & 30.369 & 23.748 & 20.958 & 23.680 \\
\hline Agustus & 22.140 & 24.982 & 12.842 & 13.548 & 9.032 & 13.072 & 22.997 \\
\hline September & 8.945 & 8.160 & 15.012 & 7.970 & 13.360 & 17.193 & 15.508 \\
\hline October & 10.856 & 10.551 & 12.448 & 6.734 & 13.352 & 16.243 & 10.645 \\
\hline November & 8.877 & 9.211 & 14.446 & 12.867 & 20.633 & 13.134 & 20.333 \\
\hline December & 18.807 & 17.239 & 32.216 & 35.569 & 57.254 & 40.025 & 44.950 \\
\hline Total & 144.827 & 149.779 & 171.087 & 175.463 & 190.728 & 278.059 & 378.649 \\
\hline
\end{tabular}

Note. The red one indicates the month of performing the mangalahat horbo bius ritual.

Source: BPS Kapubaten Samosir dalam Angka 2019

In 2012, the Mangalahat horbo bius ritual performance was not carried out due to a rejection from a group of people. In 2013, the show was held in September 2013. In 2014, this show was not held. In 2015, the show was held in August; 2016 was held in October; 2017 in July; and in 2018, the show will also be in July. From the data above it can be clearly seen that at every Mangalahat horbo bius ritual performance, the number of visitors to Samosir Island always decreases from the previous month.

Even though the ritual performance of the mangalahat horbo bius was counterproductive with the aim of attracting the number of visits to the Samosir Island area, the government continued to show it. This happened due to the power held by the Samosir Regency government. As Foucault (1977: 27) said that truth has a relationship with power; power creates knowledge and between power and knowledge influence one another.

The power of the Samosir Regency government is the truth to establish the mangalahat horbo bius ritual as a tourist attraction. The ritual performance of the mangalahat horbo bius becomes a fixed agenda in the Horas Samosir Fiesta activities. Horas Samosir Fiesta is a tourism marketing development program so that many tourists want to 
visit Samosir Regency. The Samosir Regency Government still maintains this ritual as a performance because this show is used as a project that must be held routinely every year.

\subsection{Catholic's views on Political Tourism Culture}

To smooth politics, the Samosir Regency government cooperated with Catholics in North Sumatra. The highest leaders of Catholics in North Sumatra want to be leaders (malim parmangmang) in the mangalahat horbo bius ritual performance. The performance was held on September 13, 2013 at the Tuktuk Siadong Open Stage, Samosir Regency.

The attitude of Catholics on Samosir Island is in line with the attitude of bishops throughout Asia in 1977 about the traditions, customs, and customs of a society. Regarding the mangalahat horbo bius ritual, the Catholic church was inculturated for this tradition. Inculturation as said by Sinaga (2011: 116) is a determination to maintain the core of the Christian faith, especially Christ, but simultaneously express it in the form and style of the local culture. Sinaga further illustrates, after local theology adopted the humus of local culture and growing new plants, together faithful to Christ but fresh in a new face.

Inculturation attitude results in the Catholic church may accept all kinds of values, languages, traditions, arts, and culture of a society. That acceptance is likened to Jesus Christ's acceptance of diversity and the existence of fallen humanity. Starting from such a view, then the Christian life must be lived contextually.

In connection with the attitude of inculturation, the Catholic church views the mangalahat horbo bius ritual as a preparation for the Good News, preparation of the Gospel (praeparation evangelica). The ritual practice of mangalahat horbo bius is an example (prototype) of the sacrifice of Jesus Christ on the cross. The blood of buffalo sacrificed to the ground by being speared several times is the same as Jesus' sacrifice on the cross. The views of Catholics have in common with the Parbaringin school of blood shed from each victim's eyes aimed at removing the sins of the world and giving a new awakening to the earth and humans (Anonymous, 2013: 57).

The practice of mangalahat horbo bius rituals has many similarities with the rituals of the Catholic religion. The eye of the parbaringin sacrifice is a buffalo, so the buffalo becomes a Batak totem. Totem animals are animals that carry the names of all ethnic groups. All tribes or bius are mixed or included. The buffalo identified the anesthetic; what happened to the bius was identified by the buffalo sacrifice. From this understanding, there is a resemblance to the Lamb of God. The Lamb of God, Jesus Christ, brought the fate of all the people of Israel (Jesus' followers).

Regarding moorings, there is a similarity between the moorings (borotan) and the crucifixion of Jesus on the cross. Borotan pole must be from the misti shariara sundung di Langit tree, which is a symbol of the act of creation, operation and distribution of life from the Batak God (Mulajadi na Bolon) to all creation. A mooring pole (borotan) is likened to a fetal umbilical cord in the uterus as a mooring and channel of a child likewise the function of borotan for all creation (Anonymous, 2013: 24). The sacrificial buffalo was bound at the borotan pole to atone for the sins of the world, as was the case with Catholicism, the Lamb of God (Jesus) was bound and stabbed on the cross to atone for human sins. The similarity between the horbo bius with Jesus Christ can be seen below:

Table 2.

\begin{tabular}{ll}
\hline Horbo Bius & Kristus \\
\hline 1. Deliverance from sins & 1. Deliverance from sins \\
2. From the grip of Naga Padoha & 2. Liberation from the clutches of the devil \\
3. From the clutches of reinforcements and disease & 3. Liberation from reinforcements and disease \\
4. Vegetative fertility returns: 3H: & 4. Vegetative fertility returns: 3H: \\
- Hagabeon (many offspring, elderly); & - Hagabeon (many offspring, elderly); \\
- Hamoraon: & - Hamoraon: \\
- Agricultural fertility; & - Agricultural fertility; \\
- Farm fertility; & - Farm fertility; \\
- Livelihood prosperity; & - Livelihood prosperity; \\
- Hasangapon (glory, fame) & - Hasangapon (glory, fame) \\
5. Earth's re-creation & 5. Earth's re-creation \\
6. Restoration of worldly maritime culture & 6. Restoration of worldly maritime culture \\
7. Circular time of one year (back): & 7. Linear time until doomsday (Eschaton): \\
- One-year circular absolute liturgy & - Linear liturgy is relatively one year \\
- Worldly annual "Kairos" & - Linear "Kairos" is to death \\
& 8. The certainty of the resurrection of the dead
\end{tabular}




\author{
9. There is a private court \\ 10. The existence of eternal life (Heaven) \\ 11. Punishment: \\ - Temporary punishment (washing) \\ - eternal damnation (hell)
}

(Anonim, 2013: 45)

From the explanation above, we can see the similarity between the horbo bius of the Parbaringin sect and the Jesus Christ of the Catholic religion. Of the 11 points, there are 7 points that have similarities between the two religions. Apart from the similarities between the two religions, there is a striking difference between the Batak religion and Catholicism that is, in the Batak religion there is no resurrection, no love, no trial and no eternal life.

The similarity found in the sacrifice of horbo bius on the borotan pole with the sacrifice of Jesus Christ on the cross is acceptable to Catholics. Catholics on Samosir Island can accept this understanding because the person who gives an understanding of the similarity is the highest leader of Catholics in North Sumatra. This is consistent with what Foucault (1977: 27) said, that power contains knowledge. Power and knowledge are two sides of the same process. There is no knowledge without power and no power without knowledge. The power possessed by the highest leadership of the North Sumatran Catholics (Archbishop of Medan) who could accept the mangalahat horbo bius ritual performance caused followers of the Catholic religion to consider it to be the truth.

The Mangalahat horbo bius ritual performance on Samosir Island, which is supported by Catholics, aims to broadcast religion, not for tourism. This performance is made into an arena that has many interests in it. This is consistent with what Bourdieu said that there are many interests that dominate human endeavors as much as value must be maximized and as much as the arena is available (Jenkins, 2013: 128). The Samosir Regency Government has an interest in promoting tourism in its area through the politics of cultural tourism while making it a project, while the Catholic church has an interest in broadcasting religion to the general public.

\title{
4.3 Christian Views of Political Tourism Culture
}

According to BPS Samosir data in 2015 figures, the largest number of Christians is in Samosir Regency which is 85,459 people $(56.90 \%)$; 62,613 Catholics (41.69\%); 1,524 Muslims (1,01\%); and Parbaringin flow as many as 591 people $(0.39 \%)$. Christians, in this case the Batak Christian Protestant Church (HKBP), firmly reject the mangalahat horbo bius ritual as a tourist attraction. This rejection can be seen from the results of the seminar and workshop held on Tuesday, August 4, 2015 at the Guest House Nomensen HKBP District VII Samosir.

The results of the seminar and workshop concluded:

1. Batak Christian Protestant Church rejected the mangalahat horbo ritual because it displayed sadism;

2. If the government's goal of carrying out the mangalahat horbo ritual is to bring tourists, the HKBP sees that the practice will actually prevent tourists from arriving because tourists do not like sadism;

3. In accordance with the HKBP church's strategy law chapter III, article 1, point b, page 32, that the practice of mangalahat horboy which relating to occultism is a violation of the first and second orders;

4. Theological reasons are in accordance with the 6th commandment, that humans must maintain the survival of the entire creation of God, and Mark 16:15: "Go to all the world, preach the Gospel to all beings" (Results of HKBP District VII Samosir Workshop, August 4, 2015 ).

\subsubsection{Displaying Sadism}

The ritual practice of mangalahat horbo bius is carried out with various processions. The procession begins with buffalo purification and the peak is a reshuffle several times until it collapses. Blood flowing to the ground is believed to be the atonement of the sins of the world, and only through the sacrifice of buffalo blood, the sins of the world are blotted out.

As Sinaga said (2014: 155), buffalo is a symbol of the world (middle continent) and the death of buffalo is meaningful for the elimination of the world. The elimination of the old world needs to be done so that a new world is created. The negation of the old world is symbolized by the cruel treatment of the eyes of the sacrifice of the buffalo in hopes of creating a new world. The more cruel the treatment of the sacrificial eye the better the desired new world. The cruelty committed against the buffalo is the destruction of the old sinful world into a new world full of hope. 
The cruelty or sadism exhibited against buffaloes through the practice of the mangalahat horbo bius ritual is not acceptable to the HKBP church. Buffalo as God's creation is the same as other creations not treated according to the truth. Whatever the reason, in the HKBP's view, animals are not natural to be tortured. Buffalo blood cannot atone for human sin, but only the blood of Jesus Christ was crucified at Golgata.

\subsubsection{Inhibiting Visit Interest}

The main purpose of the mangalahat horbo bius ritual performance is to attract a visit to Samosir Island. The local government of Samosir Regency packed the show in the hope that tourists would be interested in watching it. Various efforts were carried out starting from the preparation of everything needed, collaboration with the Catholic church, promotion of performances nationally and internationally, but the results were far from expectations. The mangalahat horbo bius ritual performance is only witnessed by the villagers who host the show. Tourists who are visiting leave the show because in it are showed violence against the sacrificial buffalo. The mangalahat horbo bius ritual performance usually involves hundreds of people. The cast is represented from each family included in one bius. They use local languages in the show because many terms in this ritual are very difficult to translate into Indonesian and English. Ignorance of visitors to the local language also makes their interest to watch the show. Performances are very identical to traditional ceremonies where traditional ceremonies that play a role are the dalihan na tolu elements found in the Batak tribe (Siregar, 2018: 14).

Although the ritual performance of the horbo bius inhibits the interest of the visit, the performance is still held. This may still be done because this show has become a realm as Bourdieu meant. The realm is an arena of strength in which there is an effort to struggle for resources (capital) and also for the sake of gaining certain access close to the power hierarchy (Fashri, 2014: 106). Through the ritual performance of the horbo bius, the existence of the bius kings revived, where this power had long been suppressed by the Dutch colonies. The kings of bius returned to the elite in the community. The Samosir Regency Government continues to hold it because the show is used as a project that must be done every year.

\subsubsection{Occultism}

Occultism comes from the word occult, which means secret, hidden from ordinary or mysterious human views, while ism is understanding or doctrine. Therefore, occultism can be interpreted as a teaching or understanding of things that are dark, secret, and hidden, especially the power of darkness (Pondsius, 2004: xvi). Occultism is hidden knowledge found in the universe.

Occultism is contrary to the dogma of the HKBP church, this is clearly seen in the HKBP church's strategy law Chapter III, article 1, point b page 32 which contains: "acts of sin that must be kept away:" ... .mangalahat horbo...... ". There are several types of actions that Christians must keep away from, one of which is explicitly mentioned as horbo. Mangalahat horbo is an occult act because it is against the first and second commandments of the law.

Judging from the first and second laws of the law, mangalahat horbo became occult because buffaloes as sacrificial eyes were made into sacred objects. Buffalo is a savior of humans so that it exceeds human self. The buffalo which was sacrificed on the borotan pole is likened to Jesus crucified on the cross. Similarity between the sacrifice of buffalo and Jesus' sacrifice to save the world cannot be accepted by the HKBP church.

Another reason for rejection related to this ritual performance is the purpose of worship. The ritual of worshiping horbo bius as the purpose of worship is Mulajadi na Bolon. Mulajadi na Bolon was the Lord of the Bataks when he embraced the Parbaringin sect. The entry of Christianity into the Tapanuli region resulted in the flow of Parbaringin seen as animistic beliefs (sipelebegu). All the rituals that belong to the Parbaringin sect including the horror become animism.

Animism is a discourse that is always produced by Christians to combat the Parbaringin sect. However, in daily life, very many of their actions take the form of animism, such as giving food to the grave, calling on ancestral spirits, working on Sundays, and others. These animistic activities do not get prohibited. The ritual performance of the mangalahat horbo bius was a forbidden activity because behind the performance there were other interests from the HKBP church. As Bourdieu said, in this life there are many interests. These interests are historical and cultural constructions, and can only be determined by empirical research (Jenkins, 2013: 128). Through the research that has been carried out, it is known that if the performance of the mangalahat horbo bius ritual continues, the existence of the Parbaringin on Samosir Island will increasingly exist. The existence of the Parbaringin sect is an increasingly difficult challenge to convert the Samosir Island community to Christianity. Another implication is the possibility of turning Christians into followers of the Parbaringin sect. 


\subsubsection{Theological Reasons}

Mangalahat horbo bius ritual which is used as a commodification is very contrary to the 6th commandment of the law, namely it forbidden to kill. Understanding do not kill broadly, humans must love, care for all living things. Very cruel rebellion against buffalo is an action that is very contrary to this decree. The pouring of buffalo blood to the ground by spear is meant as torture.

Another rejection related to theology is the Word of God written in Mark 16:15: "Go into all the world preach the gospel to every creature." This order is Jesus' command to His disciples to preach the Gospel to all beings without exception. Preaching the Gospel to all beings includes loving all creation and maintaining its survival. Therefore the killing and torture of buffalo is clearly contrary to God's Word.

The theological discourse constructed by the HKBP church is very reasonable, but if HKBP is consistent with its attitude to preach the Gospel to all beings. Therefore illegal logging of forests around Lake Toba should not occur. The same thing like the floating net cages that have exceeded the capabilities of Lake Toba, that make the lake water becomes dirty and disrupts the ecosystems in it. The destruction of nature and the disrupted Lake Toba ecosystem are also the responsibility of the church, but in reality the church pays little attention to this problem. It is true what Foucault said that discourse is an act of big talk without content (Aur, 2005: 152).

\subsection{Political Implications of Cultural Tourism}

The politics of cultural tourism launched by the Samosir Regency Government has internal and external implications. Internal implications: different support between Catholics and Christians for tourism programs; the polarization of Catholicism with Christianity is increasing; his life back in the traditions of the ancestors. External implications: counterproductive as a tourist attraction.

\subsubsection{Different Support between Catholics and Christians for the Tourism Program}

Government programs can succeed if the community they lead agrees with the program. Conversely, no matter how good the program made by the government if it is rejected by the community, the program cannot run well. Therefore, every government must get support from the community so that the program planned can run well. Individuals and groups will also support government programs if they are in accordance with their wishes or ideology.

Ideologies, as Barker (2014: 139) said, are binding ideas and are the basis of justification for all social groups. Ideology as a way of life shapes their identity as a group and becomes a justification for their actions. The similarity of the ideologies of various groups in the matter being discussed has resulted in their mutual support.

The similar desire to perform the mangalahat horbo bius ritual between the Samosir Regency government and Catholicism resulted in good relations between the two institutions. The Catholic Church strongly supports the Samosir Regency government program related to tourism so that the government supports the Catholic Church program. The relations between the two institutions are mutually beneficial and give each other.

The support of the Catholic Church to the local government in relation to tourism is clearly seen from the results of a seminar held on Saturday, October 15, 2016 at the St. Mikael Catholic Church, Pangururan Samosir. As the guest speaker at the seminar was the Archbishop of Medan Mgr. Anicetus Sinaga OFM Cap, Assistant Deputy for Infrastructure Development and Tourism Economy Ministry of Tourism Frans Teguh, Minister of Tourism and Culture (2000-2004) I Gede Ardika, member of the House X commission MY Esti Wijayati, Kompas reporter Tri Agung Kristanto, and Lake Toba Henri tourism researcher Sitorus and Herman Nainggolan. The seminar was also attended by Deputy Regent of Samosir, Juang Sinaga and tour operators and representatives of Samosir residents.

Recommendations from the National Seminar on Tourism and at the same time commemorating World Food Day:

1. Parishes must be involved in paying attention to social, economic, cultural and environmental issues to advance tourism.

2. Nuns are involved both in terms of education, health to support tourism development.

3. Each station is expected to participate in organizing the church environment through greening the environment cleanliness and spatial planning.

4. All believers are expected to take responsibility for preventing landslides, fires, drugs, gambling and prostitution.

From the results of this recommendation it is clear that the Catholic church is very supportive of the Samosir Regency Government's program, especially in the field of tourism. Support can be seen starting from the Parish in Samosir Island to each individual who is expected to help promote tourism. 
The politics of cultural tourism was constructed by the local government of Samosir Regency as a cultural preservation and at the same time improving the lives of the people of Samosir Island. However, as Foucault said, power in practice does not always run smoothly. Power and resistance to power are everywhere (Ritzer, 2012: 621). The HKBP church, which has the largest congregation in Samosir District, rejects the Mangalahat horbo bius ritual. The rejection of the show has implications for the poor relationship between the Samosir Regency government and the HKBP church. The HKBP Church is less concerned about government programs, especially in the field of tourism.

\subsubsection{Polarization of Catholicism with Christianity Increases}

The birth of Christianity or often called Protestant Christianity is an attempt to reform the church to oppose policies that are contrary to God's Word. The theological reform was started by Martin Luther when he put 95 propositions or theses on the door of the Wittenberg church, 31 October 1517 (Sanderson, 2010: 541; Lumbantobing, 2007: 171). The reforms that Martin Luther initiated in the body of the church resulted in the birth of a reformed church separate from its parent Catholic Church.

The basic beliefs of the two religions are the same, namely the Bible, but in religious practice there are differences. This difference is due to the perspective or interpretation of the contents of the Bible. Borrowing Foucault's opinion, a truth is influenced by the views or episteme adopted (Lubis, 2014: 75). Catholicism in developing its mission uses the inculturation approach. Inculturation is still maintaining the core of Christianity, but simultaneously express it in the form and style of local culture (Sinaga, 2011: 116). Through the inculturation approach, Catholicism can be included in all models of community traditions.In contrast to Christianity, the approach used in zending is the adjustment approach. Christianity may enter if it is in accordance with the Gospel, while those contrary to the Gospel will be shunned. The politics of cultural tourism through the mangalahat horbo bius ritual performances initiated by the government is not in accordance with the Word of God so it must be rejected.

The difference in approach between Catholicism and Christianity in the Gospel message results in increasingly strong polarization between the two. Catholics see Christianity as self-righteous and do not value the values inherent in ancestral traditions. Instead Christians view Catholics as unconverted because they still live in the traditions of their ancestors. An unfavorable view of other groups results in high polarization between Christians and Catholics on Samosir Island.

\subsubsection{Revival of Ancestral Traditions}

The entry of the Dutch Colonial into the Tapanuli region as well as carrying out missions and zending had an impact on the Batak traditions. Europeans as Said (2016: 257) treats Easterners as they wish. Westerners are labeled energetic while Easterners are lazy; Westerners are polite and Easterners are barbaric. The labeling of Westerners is always super while the East is always bad resulting in hegemony as referred to by Gramsci (2013). Westerners may be in the East and think of the East as they wish, while Easterners cannot think of Westerners. This awareness is what Said said (2016: 9) making the East a Western puppet.The existence of the Dutch as invaders as well as carrying out missions and zending had an impact on the culture of the Batak people. Samosir Island, which is believed by the Bataks as their ancestral place (Sinaga, 1997: 40) and also its cultural center, has undergone drastic changes. All traditions that were not in accordance with the wishes of the invaders were forbidden. Moreover, mangalaha horbo bius ritual which is also a forbidden tradition due to this tradition which binds brotherhood between people and also contradicts mission and zending.

The politics of cultural tourism constructed by the local government by performing the mangalahat horbo bius ritual has implications for other long-lost Batak rituals. One example of a tradition that has come back to life by involving many people (bius) is the mangase udan ritual. Mangase udan ritual is a Batak tradition that is done to ask for their rain to come from their god called Mulajadi na Bolon. If the people of Samosir Island experience a prolonged dry season, they will carry out the Mangase Udan ritual. The Dutch entry into Tapanuli made the mangase udan ritual a forbidden tradition. But after the Mangalahat horbo bius ritual performance on Samosir Island, the Mangase Udan tradition has come back to life.

\subsubsection{Counterproductive as a Tourist Attraction}

Good tourism is tourism that is mutually beneficial between destination communities and tourists. One of the good tourism is cultural tourism. Through cultural tourism, cultural renaissance arises for the community as a tourist destination. This happens because tourist destinations stimulate their pride in traditions that have almost become extinct due to various things. Through cultural tourism, community culture as a tourist destination has the opportunity to be exhibited for tourism purposes, while money earned through performances can be used to preserve its culture (Picard, 2006: 170). 
Bali Island is one example of a region that has successfully implemented cultural tourism. The success of Bali Island lifts cultural tourism because there is a mutually beneficial relationship between tourists and Balinese. As Picard (2006: 190) said, tourists' interest and curiosity about Balinese culture strengthened Balinese attention to their religion. The income they earn through tourism is also used to treat temples in Bali. Through cultural tourism, a culture that has almost become extinct is dug up for tourism purposes. Cultural excavations that have long been abandoned have an impact on the preservation of ancestral culture.

Cultural tourism in Bali is said to be successful because the culture exhibited is attractive to tourists. In contrast to cultural tourism carried out on Samosir Island, tourists are not interested in the show due to the ignorance of tourists plus the violence exhibited in the mangalahat horbo bius ritual performances. The performance was only witnessed by the local community because they were required by the village government to be there. In addition to the obligations made by the local government as well as the bius kings, the community gets free food. Whenever there is a ritual performance of the horbo bius, tourists from outside the area especially Europeans always leave the arena.

\section{Conclusion}

The politics of cultural tourism launched by the Samosir Regency government aims to attract tourists to visit Samosir Island. Through tourism ideology, economic, preservation of authentic, exotic and attractive ancestral traditions, the mangalahat horbo bius ritual is used as a tourist attraction. Since the show was made an attraction, there were pros and cons in the community. Despite the controversy, it still runs because of government hegemony.

Groups that supported the show included the Chatolic church and the king of bius (raja bius). The Catholic church supports the show because of different missions and interests, namely religious broadcasting even if ideologically conflicting. According to the support group, the mangalahat horbo bius ritual performance is not as a tourist attraction, but as a preparation for the Good News, preparation for the Gospel (praeparation evangelica). The king of bius supported the show because their existence was recognized again which was long lost due to colonialism. The Batak Christian Protestan Church frankly rejects the mangalahat horbo bius ritual because it is contrary to Christian ideology.

Determination of the ritual mangalahat horbo bius as cultural tourism has internal and external implications, and is counterproductive. The purpose of the show as a tourist attraction, but in reality becomes an obstacle to tourists visiting Samosir Island. Although this show is sounterproductive as a tourist attraction, it is still displayed due to the power relations of the Samosir Regency Government. Authentic and exotic cultural capital continues to be displayed despite the rejection of certain institutions and agencies related to the mangalahat horbo bius ritual.

The politics of cultural tourism by performing the mangalahat horbo bius ritual is an example of an inappropriate policy. Every mangalahat horbo bius ritual performance is held on samosir Island, the number of visits always decreases. It is time for the government to look for interesting cultural elements, which are exotic and authentic which did not get controversy in the community. The elements of culture that were raised to be attractive actually became an attraction rather than being an obstacle to visiting.

\section{References}

Anonim. (2011). Mangalahat Horbo Bius: Pembangunan Pariwisata Samosir. Jurnal Ilmiah Keuskupan Agung Medan.

Anonim. (2013). Mangalahat Horbo Bius: Fragmen Anamnese Pelean Horbo Bius Tahun Baru Batak. Jurnal Ilmiah Keuskupan Agung Medan.

Aur, Alexander. (2005). Pascastrukturalisme Michel Foucault dan Gerbang Menuju Dialog Antarperadaban. In Sutrisno, Mudji \& Hendar Putranto (ed). Teori-Teori Kebudayaan. Yogyakarta: Kanisius.

Barker, C. (2014). Kamus Kajian Budaya. (B. Hendar Putanto Trans.). Yogyakarta: Kanisius.

Fairclough, N. (2003). Language and Power: Relasi Bahasa, Kekuasaan dan Ideologi. (Indah RohmaniKomunitas Ambarawa, Trans.). Gresik: Boyan Publishing.

Fashri, F. (2014). Pierre Bourdieu: Menyingkap Kuasa Simbol. Yogyakarta: Jalasutra.

Foucault, M. (1977). Discipline and Punish: The Birth of the Prison. New York: Pantheon.

Gramsci, A. (2013). Prison Notebooks: Catatan-Catatan dari Penjara. (Teguh Wahyu Utomo, Pentj.). Yogyakarta: Pustaka Larasan.

Harker, Richard, Cheelen Mahar, dan Chris Wilkes. (2009). "Posisi Teoretis Dasar" (Dalam (Habitus x Modal) + Ranah $=$ Praktik Pengantar Paling Komprehensif kepada Pemikiran Pierre Bourdieu, Richard Harker, etc., 
editors. (Pipit Maizier, Pentj.) Yogyakarta: Jalasutra, halaman 1-32).

Jenkins, R. (2013). Membaca Pikiran Pierre Bourdieu. (Nurhadi, Pentj.). Bantul: Kreasi Wacana. https://doi.org/10.4324/9781315015583

Lubis, A. Y. (2014b). Postmodernisme: Teori dan Metode. Jakarta: Rajawali Pers.

Lumbantobing, D. (2007). Teologi di Pasar Bebas. Pematang Siantar: L-SAPA.

Martono, N. (2015). Metode Penelitian Sosial: Konsep-konsep Kunci. Jakarta: Rajawali Pers.

Moleong, L. J. (2014). Metodologi Penelitian Kualitatif. Bandung: PT Remaja Rosdakarya.

Picard, M. (2006). Bali: Pariwisata Budaya dan Budaya Pariwisata. (Jean Couteau and Warih Wisatsana Pentj.) Jakarta: Kepustakaan Populer Gramedia.

Piliang, Y. A. (2012). Semiotika dan Hipersemiotika: Gaya, Kode dan Matinya Makna. Bandung: Matahari.

Pondsius \& Susanna, T. (2004). Antara Kuasa Gelap dan Kuasa Terang. Batu-Jawa Timur: Departemen Literatur YPPII.

Ritzer, G., \& Douglas, J. G. (2012). Teori Sosiologi Modern. (Alimandan Trans.). Jakarta: Kencana Prenada Media Group.

Roskin, M. G., Robert, L. C., James, A. M., \& Walter, S. J. (2016). Political Science: An Introduction Pearson. (Liana Nurul Trans.). Jakarta: Kencana.

Said, E. W. (2016). Orientalisme: Menggugat Hegemoni Barat dan Mendudukkan Timur sebagai Subjek. (Achmad Fawaid Trans.). Yogyakarta: Pustaka Pelajar.

Sanderson, S. K. (2010). Makro Sosiologi: Sebuah Pendekatan Terhadap Realitas Sosial. (Farid Wajidi, S. Menno Trans.). Jakarta: Rajawali Pers.

Schreiner, L. (2002). Adat dan Injil. (P. S. Naipospos Trans.). Jakarta: PT BPK Gunung Mulia.

Sidjabat, W. B. (1982). Ahu Si Singamangaraja. Jakarta: Sinar Harapan.

Simanjuntak, P. W. T. (2011). Nommensen: Seratus Lima Puluh Tahun Jejak Missinya di Sumatera Utara. In: Bungaran Antonius Simanjuntak (ed). Pemikiran tentang Batak: Setelah 150 Tahun Agama Kristen di Sumatera Utara. Jakarta: Yayasan Pustaka Obor Indonesia.

Sinaga, A. B. (2011). Pengertian Adat dan Implikasinya terhadap Agama. In: Bungaran Antonius Simanjuntak (ed). Pemikiran tentang Batak: Setelah 150 Tahun Agama Kristen di Sumatera Utara. Jakarta: Yayasan Pustaka Obor Indonesia.

Sinaga, A. B. (2014). Allah Tinggi Batak - Toba: Transendensi dan Imanensi.Yogyakarta: Kanisius.

Sinaga, R. (1997). Leluhur Marga-Marga Batak dalam Sejarah: Silsilah dan Legenda. Jakarta: Dian Utama.

Siregar, M. (2018). Ketidaksetaraan Gender dalam Dalihan na Tolu. Journal Studi Kultural, 3(1).

Siregar, M. (2019). Marriage Ceremony in Batak Toba Tribe: Between Consumerism and Purpose of Life. International Journal of Applied Science, 2(3).https//doi.org/10.30560/ijas.v2n3p40

Vergouwen, J. C. (1986). Masyarakat dan Hukum Adat Batak Toba. (Redaksi PA Trans.). Jakarta: Pustaka Azet.

\section{Copyrights}

Copyright for this article is retained by the author(s), with first publication rights granted to the journal.

This is an open-access article distributed under the terms and conditions of the Creative Commons Attribution license (http://creativecommons.org/licenses/by/4.0/). 